Article

\title{
Landscape Pattern Changes in Response to Transhumance Abandonment on Mountain Vermio (North Greece)
}

\section{Anna Sidiropoulou ${ }^{1}$, Maria Karatassiou ${ }^{1, *}$, Georgia Galidaki ${ }^{2}$ and Paraskevi Sklavou ${ }^{3}$}

1 Laboratory of Rangeland Ecology, Department of Forestry and Natural Environment, Aristotle University of Thessaloniki, P.O. Box 286, Thessaloniki 54124, Greece;

E-Mail: asidir77@for.auth.gr

2 Laboratory of Forest Management and Remote Sensing, Department of Forestry and Natural Environment, Aristotle University of Thessaloniki, P.O. Box 248, Thessaloniki 54124, Greece; E-Mail: galidaki@for.auth.gr

3 Laboratory of Range Management, Department of Forestry and Natural Environment, Aristotle University of Thessaloniki, P.O. Box 236, Thessaloniki 54124, Greece;

E-Mail: psklavou@for.auth.gr

* Author to whom correspondence should be addressed; E-Mail: karatass@for.auth.gr; Tel.: +30-231-099-2302; Fax: +30-231-099-2729.

Academic Editor: Audrey L. Mayer

Received: 28 September 2015 / Accepted: 16 November 2015 / Published: 23 November 2015

\begin{abstract}
Transhumance, the seasonal movement of herds between highlands and lowlands following precise, repeated routes, is a common practice in many Mediterranean regions. This livestock movement exploits natural vegetation in both winter and summer pastures. In Greece transhumant herders, drawn by relatively abundant vegetation, usually relocate to mountainous areas between April and October. Mount Vermio was an ideal summer pasture for the nomadic, ethnic group Sarakatsanoi of Thessaly, who used to own big herds. Socio-economic conditions of the 20th century led to the gradual decline of transhumance, resulting in reduction in grazing pressure and changes in vegetation dynamics. The purpose of this study was to monitor changes in landscape patterns in response to transhumance abandonment. Landscape metrics were employed to estimate land use/cover in two altitudinal zones. Results reveal that due to the abandonment of transhumance in the highlands landscape fragmentation increased. Meanwhile, in the lowlands, due to the uninterrupted presence of animals, landscape structure is more stable and diversified. Grasslands and agroforestry systems became smaller and more isolated. In
\end{abstract}


conclusion, the abandonment of transhumance led to the overall deterioration of the rural landscape in the highlands.

Keywords: landscape metrics; land-cover changes; GIS; spatial analysis; Sarakatsanoi

\section{Introduction}

Transhumance is the cyclical, annual migration of livestock between high elevation rangelands (summer pastures) and low elevation rangelands (winter pastures), to exploit their seasonal growth and avoid harsh, seasonal weather conditions, such as cold winters and hot summers, respectively [1-3]. In the Mediterranean area, this has been a common practice adapted to climate variability for centuries [4-6]. Approximately half a year, animals are kept on the lowlands (winter pastures) grazing on common land and/or on fallow cropland during the winter. From spring to autumn, flocks accompanied by humans tending them, are moved to highlands (summer pastures) to graze the lush forage that grows on these areas during the summer period [1,7]. They typically return back to lowlands in the middle to end of autumn.

Traditionally, transhumant flocks were moved on foot following rather fixed routes that facilitated commercial activities, accommodation, and complementary farming activities, giving rise to long term settlements [8]. The importance of these routes is reflected in the variety of names used in different regions of the Mediterranean to describe them, namely tratturi in Italy, cabañeras in Aragón, azadores reales in Valencia, carreradas in Catalonia, carraires in Provence, caminhos in Portugal, cañadas reales - royal transhumance routes - in Castilla y León [9], and vlachostrata in Greece [10].

Grazing pressure of flocks, on both winter and summer pastures, exerted a strong effect on vegetation dynamics [11-13], in forage quantity and quality [14], and in species and community diversity [15-17]. Grazing also has an impact on the spatial heterogeneity of vegetation, affecting ecosystem processes and landscape diversity $[18,19]$. Grazing and other pastoral activities, especially in summer pastures, create openings and corridors in forests and rangelands resulting in the emergence of mosaic-like landscapes and vegetation changes both along the routes and on highland rangelands [20-22]. The size of these changes is such that transhumance is considered key landscape shaping factor and not just ecological disturbance mechanism [23]. It is this type of animal husbandry that preserves two very important landscape types, rangelands, and open forests. Reduction in grazing can result in expansion of forest and shrublands at the expense of semi-natural grasslands $[1,24,25]$.

In Greece, pastoral activities date back to 6500 B.C. at the beginning of the Neolithic era [26]. Long-distance transhumance however was absent, since it required high demand for pastoral products and a politically unified territory that was not common at this historic time [27]. During the Ottoman Empire, the transhumance nomadic livestock farming system was gradually developed [28]. Greek transhumant herders, drawn by relatively abundant vegetation and mild temperatures, grazed from October to April in various coastal plains. As summer approached, they moved to highlands where melting snow produced rich forage [8].

Transhumance in Greece took the form of societal organization in which large, independent family groups migrated with, and organize their lives around livestock husbandry [8]. Several ethnic groups 
such as "Sarakatsanoi", "Karagkounoi", "Vlachs", and "Koupatsaroi" are linked with this pastoral activity [1]. Sarakatsanoi, in particular, are considered the ethnic group closest to ancient transhumance and they appear all over continental Greece, especially in Thrace and Thessaly [29-31]. In the past, they did not own any pastures, nor had permanent residencies at their summer or winter encampments. However, in 1919, "enoikiostasio"—rent control—was included in Greek legislation and Sarakatsanoi were obliged to use the same summer and/or winter pastures every year [1,30,31].

Competition for summer pastures on the mountains of northern Greece was intense in the past [32]. According to Chatzimichali [33], Mount Vermio, located in central-north Greece, accommodated 66\% of the goat and sheep of Macedonia. It was easily reached and had abundant grasslands that retained summer vegetation because of the altitude and the frequent rainfalls [32]. For the Sarakatsanoi of Thessaly (Figure 1), it was an ideal summer pasture, therefore, around 1918, they started colonizing it [32].

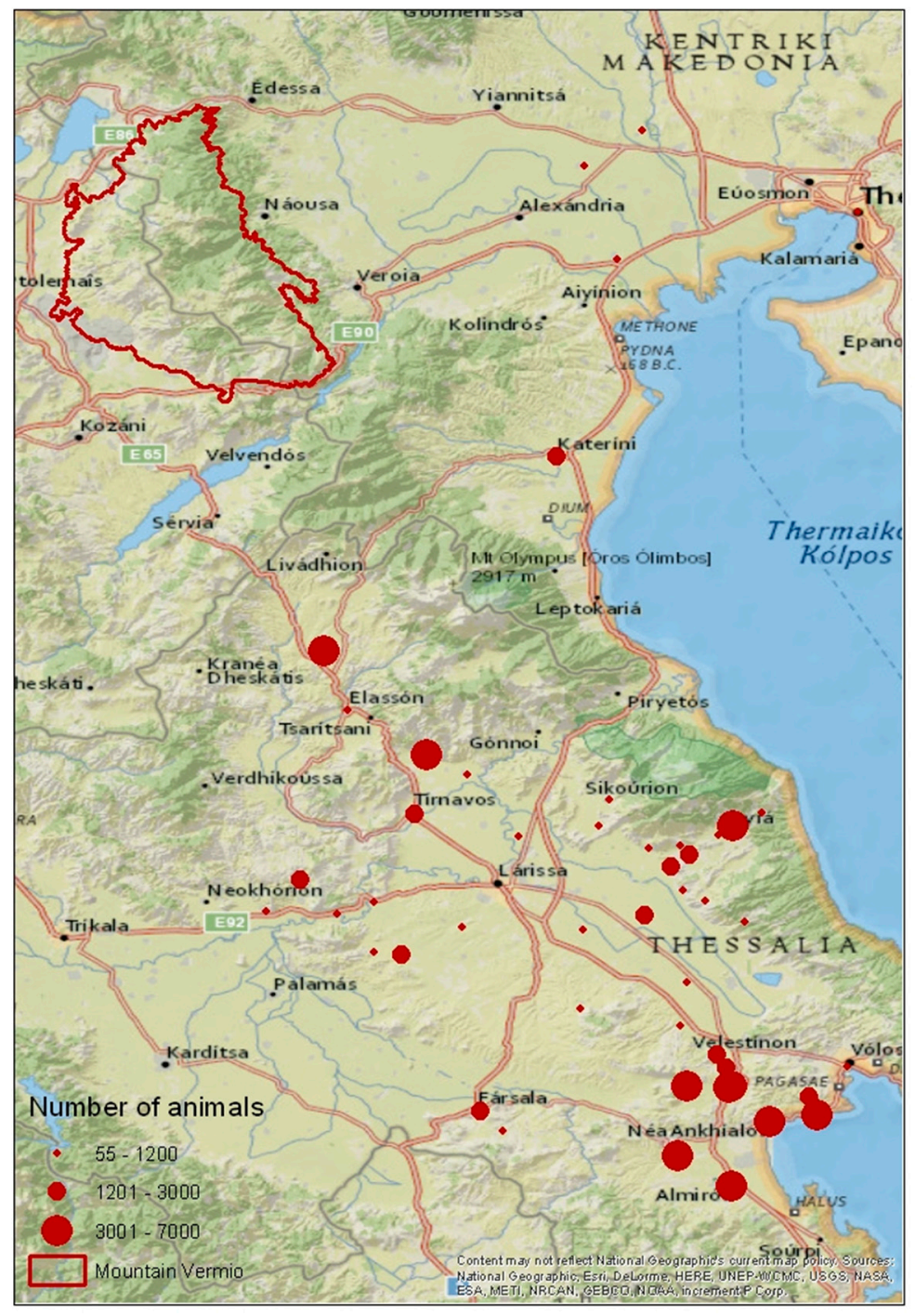

Figure 1. The main bulk of the Sarakatsanoi in Mount Vermio originated from the Thessaly area.

The map depicts the number of animals per winter pasture (processed, adapted data, from Chatzimichali, 1957).

The seasonal migration of flocks - "on foot" movement - from Thessaly to the summer pastures of Vermio, lasted 8-10 days and nights and followed the same route each year. The flocks were 
accompanied by the herders and their entire family, as well as horses, mules, and donkeys carrying all their belongings [32]. Since they did not have permanent residencies, they used to build new reed huts every year, or repair old ones [32,34]. Sarakatsanoi were organized in autonomous, closed societies, called "tseligkato" which all kinds of professions (grocers, cheese makers, tailors, bakers, etc.) that ensured autonomy [1]. These social structures had high cultural identity, social cohesion, and effective use of resources [30,33].

According to Chatzimichali [33], in 1950s there were 177 families of Sarakatsanoi with a total number of animals 224,820 sheep and goats on Mount Vermio. Katsaros [32] questions these figures and concedes that the animals did not exceed 150,000-170,000, attributing this discrepancy in Chatzimichali's inventory being based on personal information from Sarakatsanoi, who exaggerated the size of their flocks in order to increase their social status.

Since the beginning of the 20th century, socio-economic conditions including the agricultural reform, World War II, the restriction of grazing in mountainous areas, and rural depopulation, resulted in a decrease of transhumance practices $[1,11,35]$. Nowadays, the "tseligkato" system has become almost extinct and Sarakatsanoi have settled in villages near the summer or winter pastures $[28,36]$. Transhumance is replaced by a type of vertical trasteminance. Grazing period in summer pastures has shrunk to approximately four months and most shepherds feed their animals with small quantities of grain during the whole summer [11].

The abandonment of traditional transhumance practices triggered changes in vegetation composition in remote areas due to secondary succession [11]. This modification could have significant consequences on landscape diversity [37,38]. Multi-temporal analysis of landscape pattern could provide useful insights on the impact of transhumance abandonment on land-use/cover changes [39].

The current status of all landscapes, especially in the Mediterranean area, is the result of land uses and management regimes or policies [40]. It is widely accepted that information of land use evolution is fundamental for ecological research, especially for studies linking the influence of socio-economic factors on land management practices and the distribution of current and future forms of land use [41]. The quantification of landscape structure is fundamental to understand the relationship between structure, ecological, and socio-economic processes [42,43]. For this purpose, several landscape metrics that quantify spatial heterogeneity have been developed $[44,45]$.

Landscape metrics depicting spatial features (configuration, distribution, proximity, etc.) are crucial for ecological processes taking place in a landscape [46,47] and have been used to (a) compare the spatial heterogeneity among different landscapes [48-51]; (b) to study temporal evolution of landscape dynamics [52,53]; and (c) to monitor landscapes [54-58].

Landscape metrics can be calculated for individual patch (discrete areas of relatively homogeneous environmental conditions), class (aggregation of same type of patches) and overall landscape [46,59]. Patches are the basic "building blocks" of landscape structure and most metrics derive from their spatial character and distribution [53]. They are surfaces that differ in appearance from their surroundings and vary in size, shape, and type [60]. At the class and landscape level, some of the metrics quantify landscape composition, while others quantify landscape configuration. Landscape composition and configuration can affect ecological processes independently and interactively $[61,62]$. Thus, it is especially important to understand which aspect of landscape pattern is being quantified by each metric. 
A large number of metrics, that describe multiple aspects of landscape pattern, are available [46], such as (a) area metrics (e.g., class area-CA) concerning the size of patches; (b) patch density and size metrics (e.g., number of patches-NumP, average size of patches-MPS); as well as (c) shape metrics (e.g., mean shape index-AWMSI); and (d) diversity metrics (e.g., proximity index-MPI, Shannon's diversity index-SDI, Shannon's evenness index-SEI) including patch diversity, evenness, and proximity.

The effects of transhumance on landscape structure have not been studied in detail, both in Greece and worldwide. The importance of historical cartography and the GIS environment as an integrated methodology to rediscover transhumance landscapes and integrated planning was emphasized by many authors [63,64]. Russo, et al. [65] investigated the transition from transhumance to fixed site stock-breeding by elaborating indices such as farm size and continuation of farming. Olea and Mateo-Tomás [66] analyzed transhumant activity in the uplands of the Cantabrian Mountains, NW Spain, and found that there was a strong spatiotemporal adjustment in the use of these mountain areas by transhumant livestock. In Greece, Mitka, et al. [67] investigated temporal landscape changes due to the cessation of transhumance practices on Mount Pindos, using landscape indicators, and Sklavou, Karatassiou, and Sidiropoulou [21] analyzed the evolution of vegetation and landscape on Mount Vermio, however, both studies were carried out after 1963, when transhumance was already starting to decline.

- The current study attempts to enhance the comprehension of the impact of transhumance on landscape pattern, provide basic information for assessing potential ecological threats and promote sustainable land-use planning using landscape metrics. Landscape metrics are used as a tool for the analysis and interpretation of land use/cover changes in Mount Vermio due to transhumance abandonment. To this end, the specific objectives of this study were to create land cover maps of Mount Vermio for 1945 and 2009.

- To estimate a set of landscape indices, which reveal qualitative and quantitative characteristics of the landscape, for 1945 and 2009.

- To assess and interpret the impacts of transhumance abandonment on the landscape, for the entire study area, as well as for two altitude zones separately.

\section{Materials and Methods}

\subsection{Study Area}

The study area is Mount Vermio, located in central-west Macedonia (Figure 2). Mount Vermio has a North-South orientation and is administratively shared by three prefectures: Imathia, Kozani, and Pella. The study area covers $c a .94,000$ ha in an altitudinal zone spanning from $700 \mathrm{~m}-2052 \mathrm{~m}$ above sea level. 


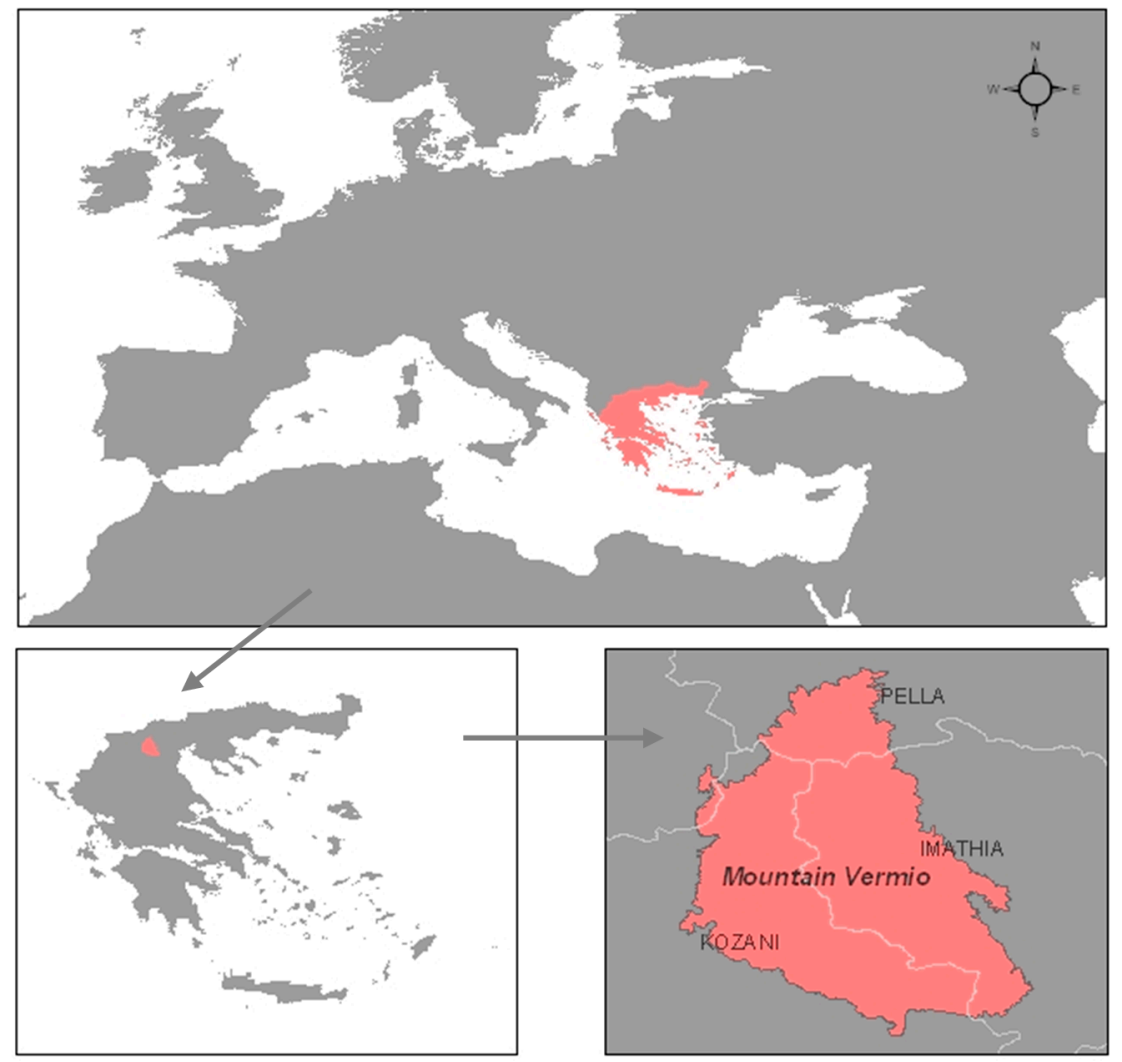

Figure 2. Location of study area at Mount Vermio.

Mount Vermio has mostly gentle-moderate slopes. Northern exposures predominate, mainly on the Northeast part of the mountain, followed by eastern, southern, and western exposures [68]. The climate is sub-Mediterranean in the uplands and meso-Mediterranean in the lowlands. Minimum rainfall occurs during the July-August period, but the atmosphere is never totally dry due to the vicinity to archipelagos [69].

Forests and woodlands are found mainly on the eastern part of the mountain. Numerous plant species such as Pinus nigra Arn., Abies borisii-regis Mattf., Castanea sativa Miller., Ilex aquifolium L., Juniperus sp., Quercus sp., Salix sp., Populus sp., Platanus sp, Acer sp., Fraxinus sp., Buxus sempervirens L., Cornus sp., Prunus sp., and Robus sp. can be found in this ecosystem [69].

\subsection{Methodology}

Up until 1960, transhumance was still practiced intensely on Mount Vermio. For the landscape change analysis, datasets for 1945 and 2009, before and after the radical decrease of transhumance on the study area, were collected. The locations of the Sarakatsanika tseligkata were obtained from Katsaros [32]. The verification of their exact location was possible using the aerial photographs of 1945 provided by the National Cadastre and Mapping Agency S.A. (NCMA S.A.) [70] (scale 1:5000), as well as topographic maps of 1953-1955 provided by the American Military Geographic Service (AMS) [10] (scale 1:50,000) where several locations were marked as "kalivia" (huts) followed by the name of the leader herder (e.g., Arkoúdha) (Figure 3). 


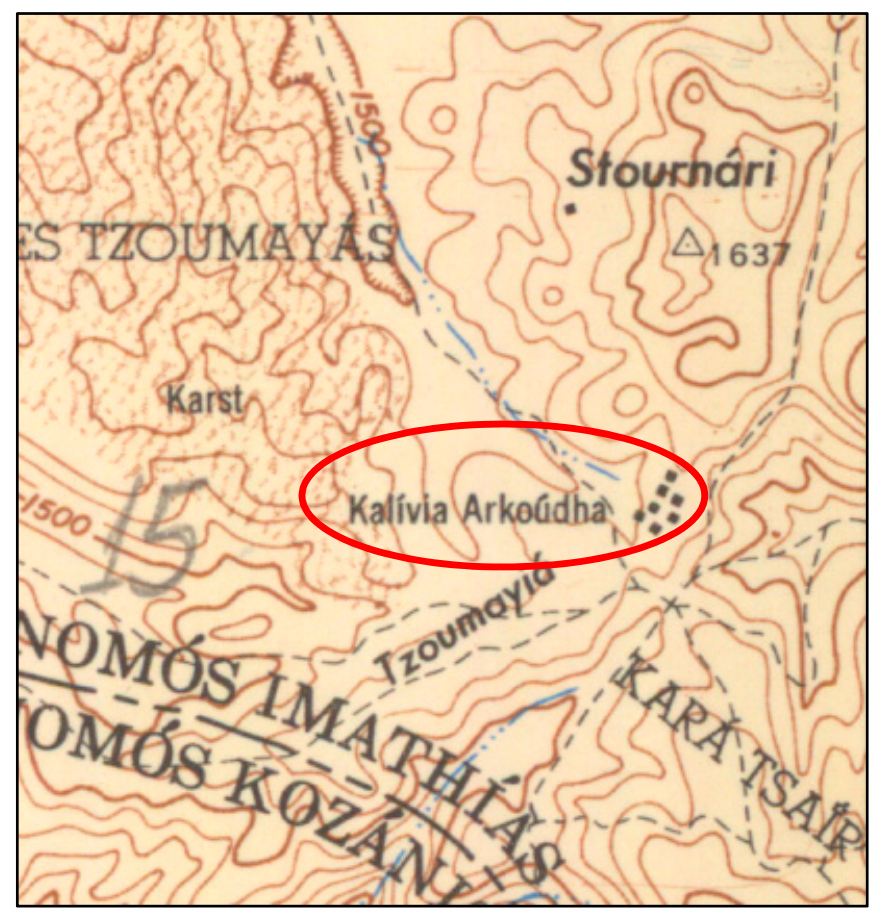

Figure 3. Sarakatsanika tseligkata on Mount Vermio, on the topographic maps of the American Military Geographic Service (1953-1955), indicated by the word "kalivia" and the name of the leader herder (scale 1:50,000).

The altitude stratification of Sarakatsanika tseligkata was based on the ASTER Global Digital Elevation Map (GDEM) [71]. For the land cover classification of the study area, two orthophotograph mosaics were produced, using aerial photography surveys of 1945 and 2007-2009 [70]. The spatial resolution of the mosaics is $0.5 \mathrm{~m}$ and their scale is 1:5,000. Land cover information was generated through photointerpretation and delineation of land cover polygons on these orthomosaics, according to the fixed classification scheme (Table 1). The digitizing exercise was implemented in 1:10,000 scale, with 1 ha minimum mapping unit, within a Geographic Information System (GIS) environment.

Table 1. Classification scheme of land use/cover in Mount Vermio.

\begin{tabular}{ll}
\hline Land Use/Cover Class & \multicolumn{1}{c}{ Description } \\
\hline Grasslands & Areas dominated by herbaceous plants, with ground cover of woody \\
& vegetation less than $10 \%$ \\
Shrublands & Areas dominated by evergreen woody shrubs with sclerophyllous leaves \\
Agroforestry systems & Areas dominate by herbaceous plants, with ground cover of woody \\
(Open grazed forest) & vegetation between $10 \%$ and $40 \%$ \\
Forests & Areas with relative tree cover higher than $40 \%$ \\
Agricultural land & Fields with permanent or temporary crops \\
Other land & Areas with manmade features, including villages, mining fields, etc. \\
\hline
\end{tabular}

Patch Analyst Extension for ArcGIS 10.1 software [72] was used to compute quantitative metrics for describing landscape structure [46]. The most appropriate metrics were chosen, based on previous multi-temporal landscape studies [48,53,73-75]. Metrics were calculated on both landscape and class 
level (Table 2). Classes corresponded to the different land use types and each class consisted of numerous polygons (patches).

Table 2. List and description of metrics used in the study [46,76].

\begin{tabular}{|c|c|c|c|c|c|}
\hline Landscape Metric & Abbreviation & Description & Unit & $\begin{array}{c}\text { Land-scape } \\
\text { Level }\end{array}$ & $\begin{array}{l}\text { Class } \\
\text { Level }\end{array}$ \\
\hline Class Area & $\mathrm{CA}$ & Sum of areas of all patches & ha & - & $\checkmark$ \\
\hline Number of Patches & NumP & Total number of patches & - & $\checkmark$ & $\checkmark$ \\
\hline Mean Patch Size & MPS & Average patch size & ha & $\checkmark$ & $\checkmark$ \\
\hline $\begin{array}{c}\text { (Area Weighted) } \\
\text { Mean Shape Index }\end{array}$ & AWMSI & $\begin{array}{l}\text { Measure of shape complexity. The index } \\
\text { equals one when all patches are circular or } \\
\text { square and increases as patch shape becomes } \\
\text { more irregular }\end{array}$ & - & $\checkmark$ & - \\
\hline $\begin{array}{l}\text { Mean Proximity } \\
\text { Index }\end{array}$ & MPI & $\begin{array}{l}\text { Measure of degree of patch isolation and } \\
\text { fragmentation within a specified radius. } \\
\text { Integrates information on size and distance of } \\
\text { like patches from a specified focal patch } \\
\text { within a defined radius }\end{array}$ & - & $\checkmark$ & $\checkmark$ \\
\hline $\begin{array}{c}\text { Shannon's Diversity } \\
\text { Index }\end{array}$ & SDI & $\begin{array}{l}\text { Measure of relative patch diversity. The index } \\
\text { equals zero when there is only one patch in } \\
\text { the landscape and increases as the number of } \\
\text { patch types or proportional distribution of } \\
\text { patch types increases }\end{array}$ & - & $\checkmark$ & - \\
\hline $\begin{array}{c}\text { Shannon's Evenness } \\
\text { Index }\end{array}$ & SEI & $\begin{array}{l}\text { Measure of patch distribution and abundance. } \\
\text { It is equal to zero when the observed patch } \\
\text { distribution is low and approaches one when } \\
\text { the distribution of patch types becomes more } \\
\text { even }\end{array}$ & - & $\checkmark$ & - \\
\hline
\end{tabular}

Class area (CA) is a measure of landscape composition. It refers to the abundance of a particular type of patch, without taking into account its spatial nature or location [46]. It provides basic information regarding the landscape that can be used in a variety of applications such as land use change analysis [60,77-79], strategic landscape planning [37], and planning of natural resources and wildlife management $[62,80,81]$.

The number of patches (NumP) is a measure of landscape configuration. It refers to the spatial character of a class or a landscape, and indicates the extent of fragmentation [46]. NumP is proportional to the landscape area, e.g., the larger the landscape, the greater the chance of containing a greater number of patches. Therefore, the comparison of the index between landscapes with different size is usually problematic [82]. From an ecological point of view, more patches in a landscape ensure landscape abundance, thus reducing the risk of losses due to disturbances such as fire, flood, epidemics, etc. According to Franklin and Forman [83], if a class is divided into a larger number of patches, it can be more resistant to disturbances and therefore more likely to be maintained.

The average size of patches (MPS) is a measure of landscape subdivision. According to McGarigal and Marks [46], it is perhaps the most important and useful information that can be derived from 
landscape analysis. Patch size affects biomass, productivity, nutrient storage, composition, and diversity of species [60]. The average size of patches can serve as an indicator of landscape function and fragmentation providing direct estimates regarding the populations of animals a landscape can support [84].

Mean shape index (MSI) is a measure of patch complexity. Simple patches shapes such as circles and squares have different effects on ecological functions and human management than more complex ones. Patch shape affects the size and nature of patch interaction with the environment, mainly through the edge effect phenomenon, which refers to changes in the microclimate, the disturbances, the ecological processes, etc., on the outskirts of neighboring patches [37]. As shape complexity increases, so does edge habitat abundance.

The proximity index (MPI) provides a measure of patch isolation and landscape configuration [85]. This is a unit free index that contributes mainly to comparative analyzes between different patches in a landscape or between spatial configuration of patches in different landscapes.

Shannon's diversity (SDI) and evenness (SEI) indices have been widely used in a variety of environmental applications [46]. SDI refers to the number of different patch types, while SEI to the distribution of different patch types in an area. These indices express the degree of disorder (entropy) in an ecosystem (natural or artificial) and hence the degree of their criticality $[86,87]$. Diversity is a well-known property of ecosystems which is very useful in the characterization of heterogeneity in time and space. Ecosystems with great diversity display great stability. Measuring landscape diversity is useful not only for land use change evaluation, but also for the prediction of potential impact on the structure and function of alternative land uses. In the Mediterranean basin, diversity is proven to be intrinsically associated with landscape heterogeneity and man-induced land use changes [88-90].

In the past, transhumance was mainly practiced between 1800-1100 m and only few tseligkata were located below $1100 \mathrm{~m}$. Today, transhumance is almost abandoned except seven tseligkata that still exist in the $1800 \mathrm{~m}-1100 \mathrm{~m}$ zone. In the last decades however, a new grazing system appeared, a type of vertical trasteminance, where animals graze below the $1100 \mathrm{~m}$ threshold. For a more detailed analysis, two altitudinal zones were distinguished: high (1800 m-1100 m) and low (700 m-1100 m).

\section{Results and Discussion}

Based on the topographic maps of the American Military Geographic Service (AMS) [10] and data from Katsaros [32], 27 summer pastures in total served the tseligkata in the past. The number of horses and mules that followed the flocks exceeded 7000. The majority of tseligkata were located at an altitude of approximately $1500 \mathrm{~m}$, with the lowest being at $1100 \mathrm{~m}$. Today, only seven tseligkata exist on Mount Vermio [21] (Figure 4). 


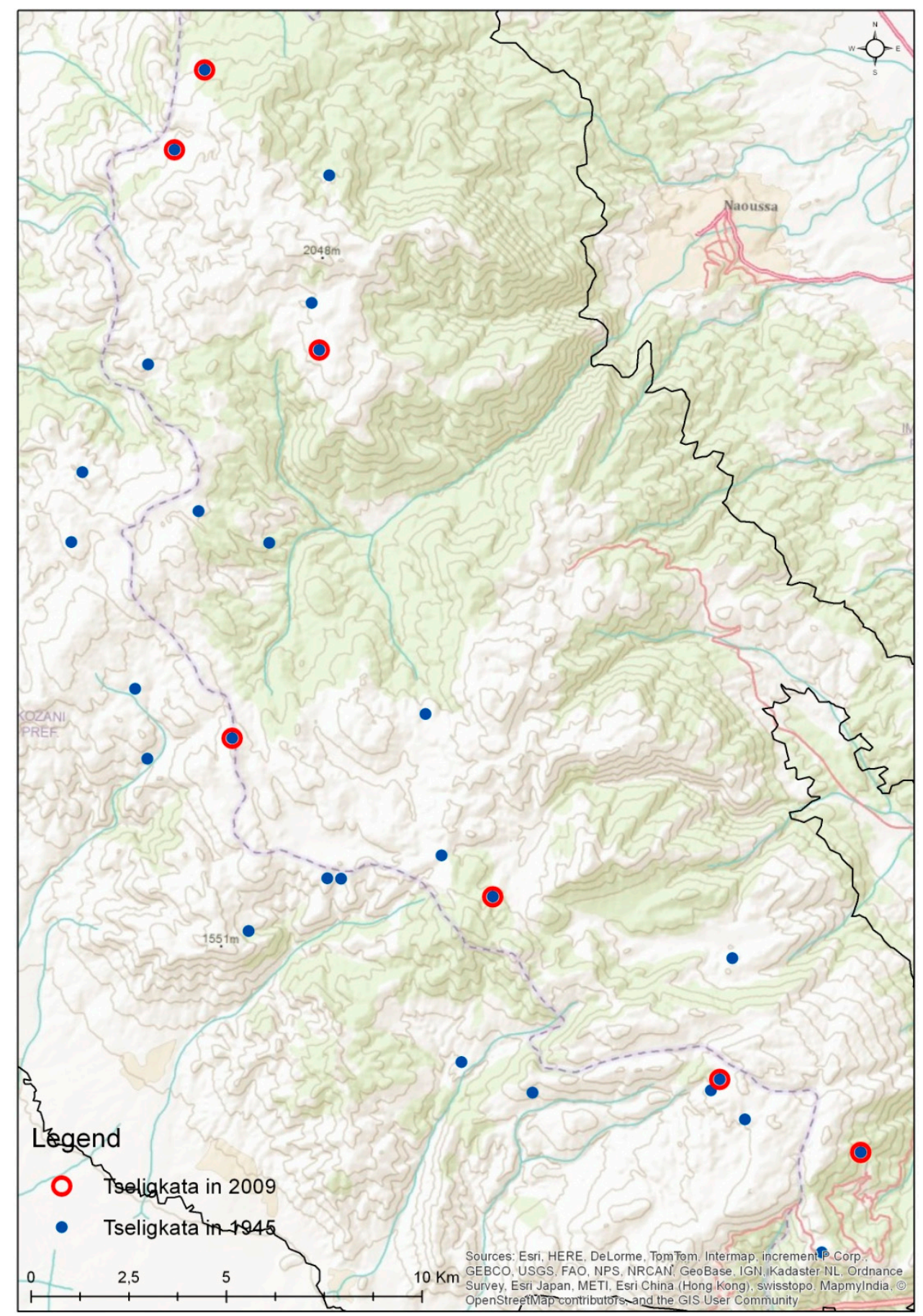

Figure 4. Locations of Sarakatsanika tseligkata on Mount Vermio before 1950 (blue dots) and in 2009 (red circles).

The average grazing extent of each tseligkato was 1212 ha, within a $2 \mathrm{~km}$ radius approximately from the shed (Figure 5). Today, transhumance is replaced by a type of vertical trasteminance where flocks are hosted in permanent sheds in the villages and graze nearby [7]. According to the Payment and Control Agency for Guidance and Guarantee Community Aid (PCAGGCA) [91], there are currently 27,532 sheep, goats, and cattle freely grazing in Mount Vermio. They typically graze pastures surrounding their sheds, in a radius not greater than $250 \mathrm{~m}$ (Figure 5). 

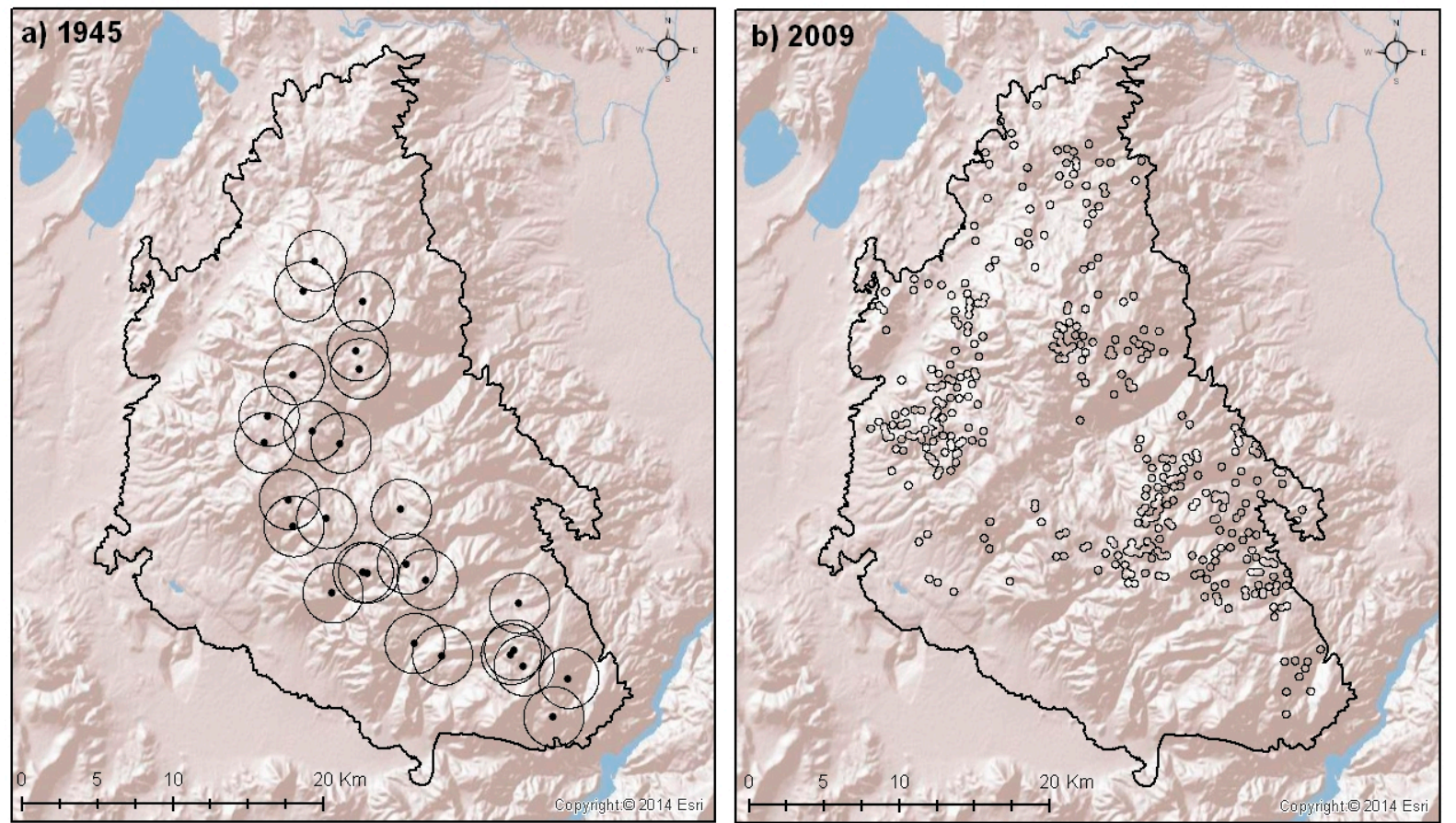

Figure 5. Spatial distribution of grazing on Mount Vermio. The circles indicate the (a) $2 \mathrm{~km}$ radius of animal movement around each shed/tseligkato in 1945; and the (b) $250 \mathrm{~m}$ radius of animal movement around the current permanent sheds in 2009.

The significant decrease of grazing animals led to land use/cover changes ((Figure 6). Comparative data analysis between 1945 and 2009 showed a substantial decrease in rangelands (grasslands, shrublands, and agroforestry systems) and agricultural lands and an increase of forests and other land uses.

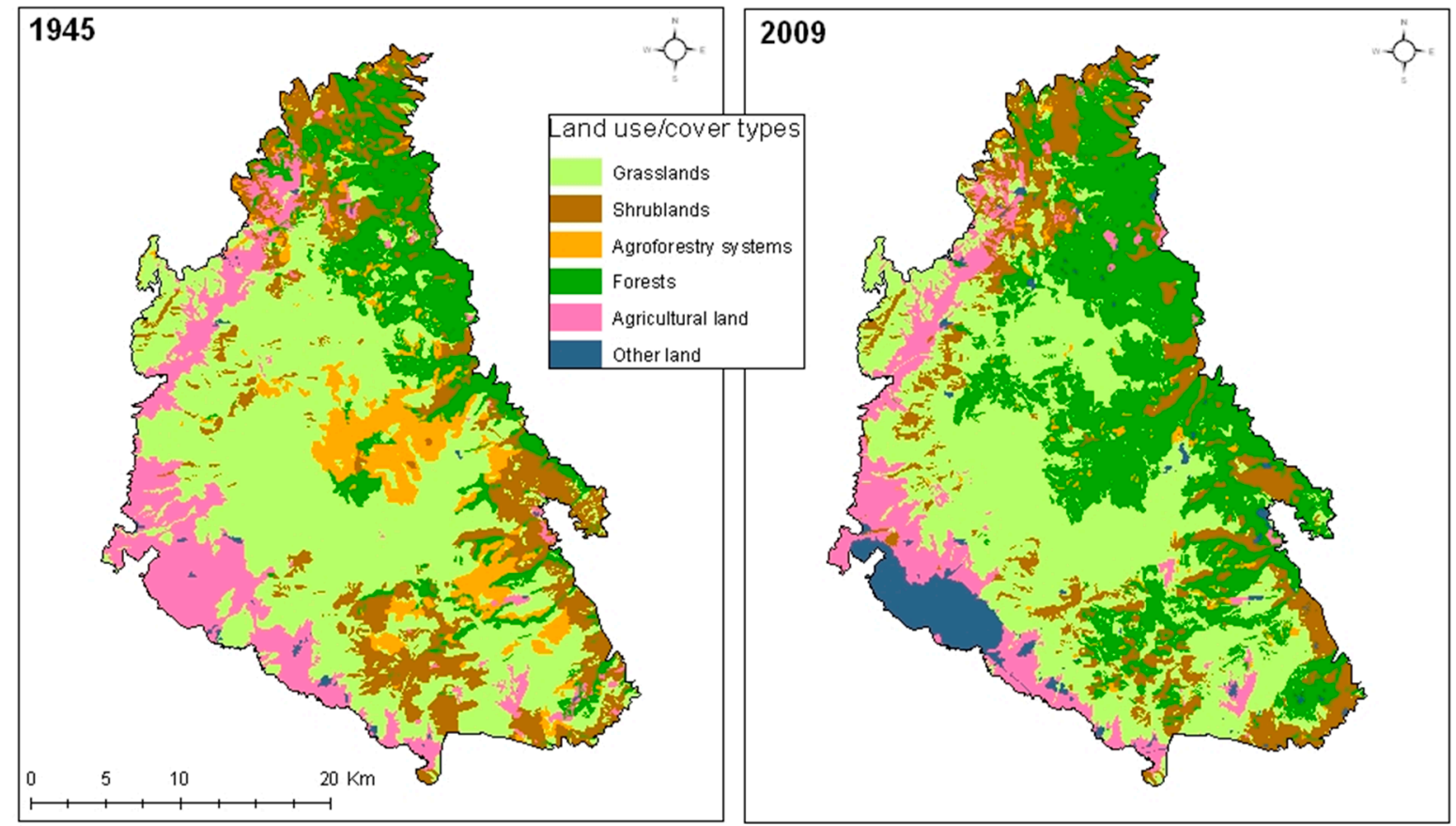

Figure 6. Land use/cover changes on Mount Vermio in 1945 and 2009. 
More specifically, grasslands, shrublands, and agroforestry systems decreased by $13.6 \%, 12.6 \%$, and $86.98 \%$, respectively, agricultural land decreased by $29.8 \%$, while forests increased by $102.1 \%$ and other land uses by $1054.4 \%$ (Figure 7). The above increase of other land uses could be attributed to the establishment of a mining field in the southwestern part of the study area near the village Karioxori, which covers the greatest part of Greece's needs for lignite and electricity production.

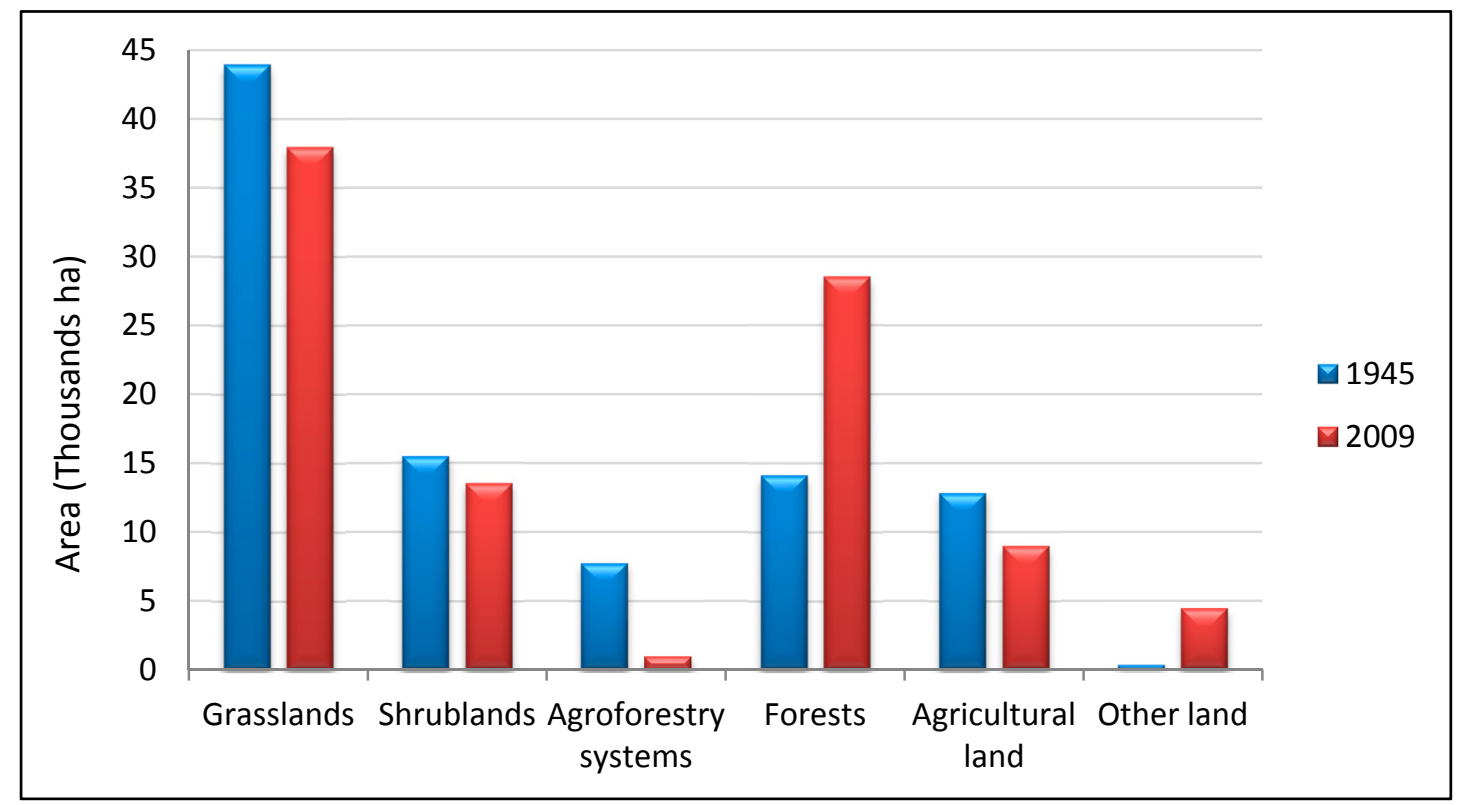

Figure 7. Land use (thousands ha) in the experimental area on Mount Vermio in 1945 and 2009.

The changes in rangelands and forests were the result of a declining trend in transhumance livestock system in Mount Vermio during the last 30 years [21], common to other mountainous areas, both in Greece and other Mediterranean countries [17,92,93]. The abandonment of transhumance was the result of various socio-economic factors that have significantly influenced the lifestyle of herders and the landscape in mountainous ecosystems and rural areas [21,94]. Spatial pattern of grazing creates habitat heterogeneity in the landscape and influences species richness in different ways.

Land use/cover changes between 1945 and 2009 point out a trend towards fragmentation and complexity, manifested in a decrease in homogenization, with a larger number of patches (NumP) and a decrease of their average size (MPS) (Figure 8). The overall decline of livestock pressure produced an acceleration in the process of plant succession with woody plants [95]. 

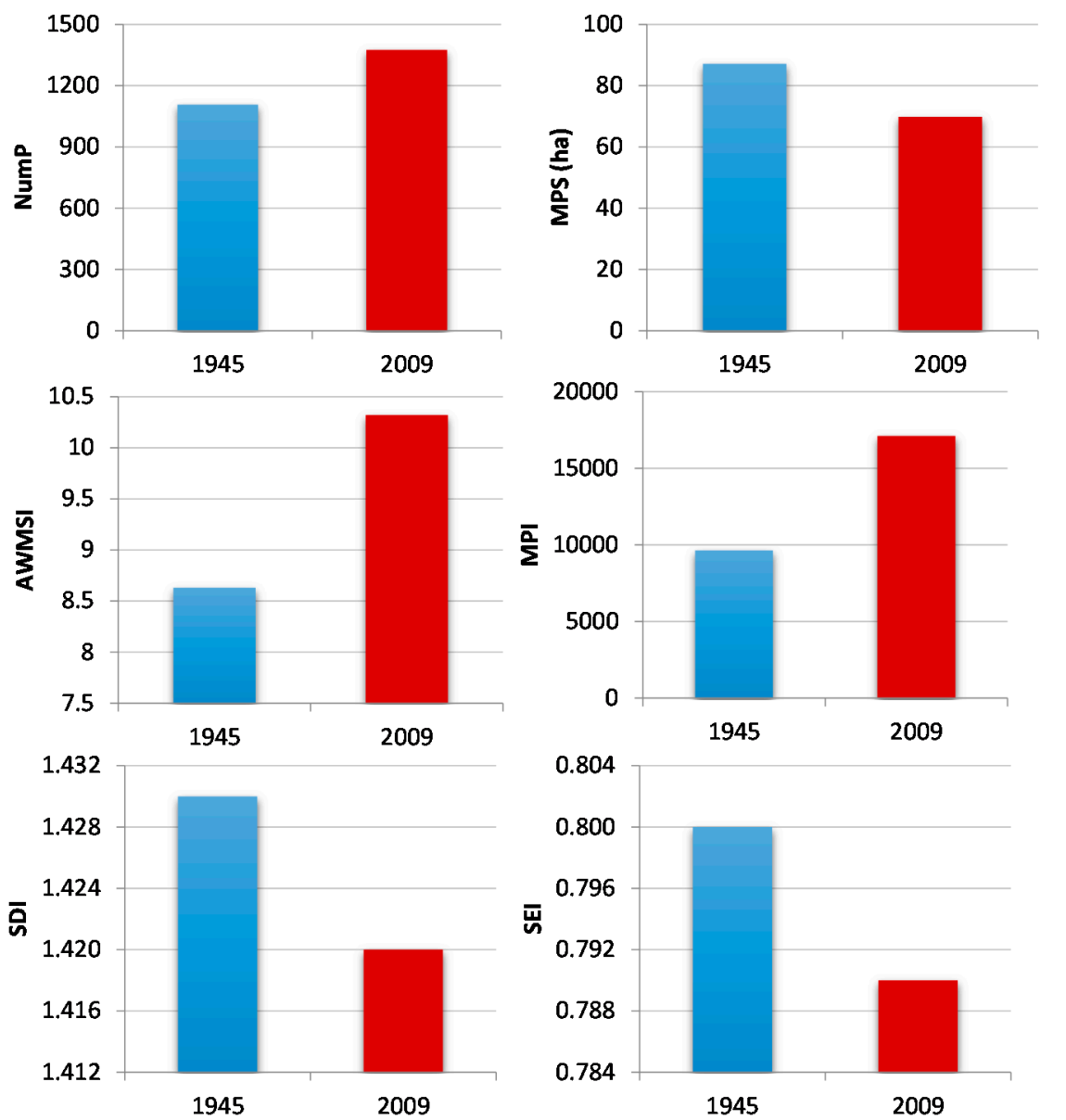

Figure 8. Landscape metrics for the entire landscape of Mount Vermio.

\section{Landscape Change Analysis per Altitudinal Zone}

Changes in landscape diversity between 1945 and 2009 were examined in the high $(>1100 \mathrm{~m})$ and low (700 m-1100 m) zone. Both Shannon's Diversity (SDI) and Shannon's Evenness (SEI) Indices indicated differences in landscape heterogeneity (Figure 9). Specifically, landscape structure on the lowlands of Mount Vermio is more stable and diversified, both in 1945 and 2009, possibly due to the uninterrupted presence of animals.

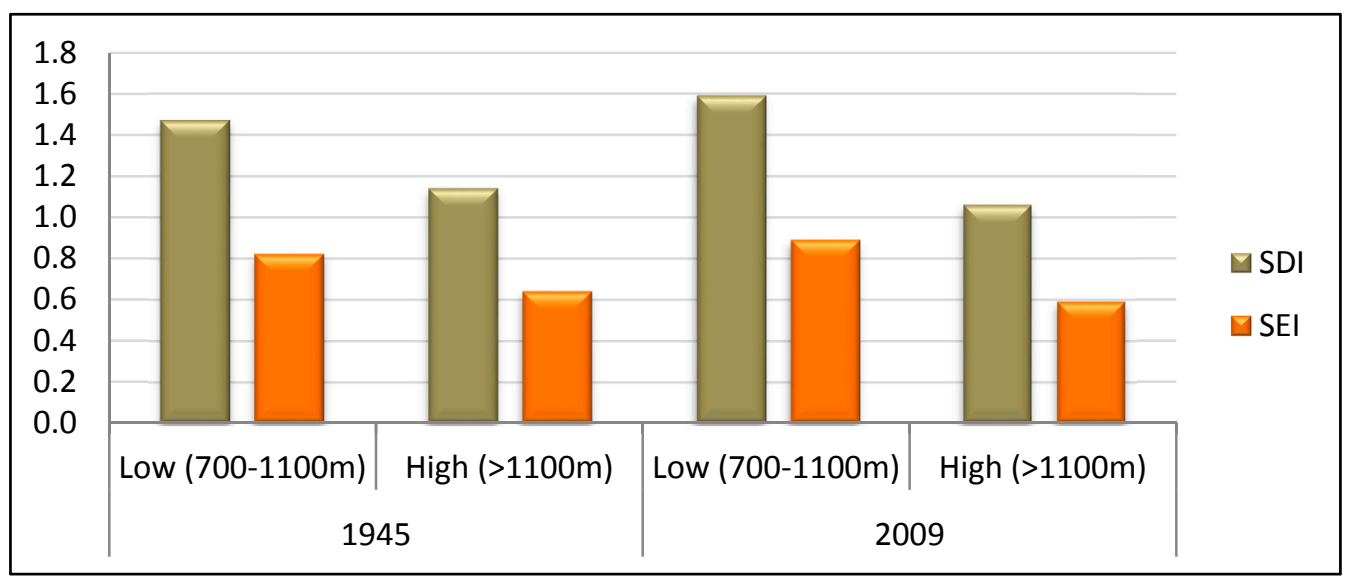

Figure 9. Shannon's Diversity (SDI) and Shannon's Evenness (SEI) Indices per altitudinal zone on Mount Vermio between 1945 and 2009. 
Land use metrics for each land use category (class) in each zone were calculated in order to interpret changes in landscape between 1945 and 2009 (Figure 10).
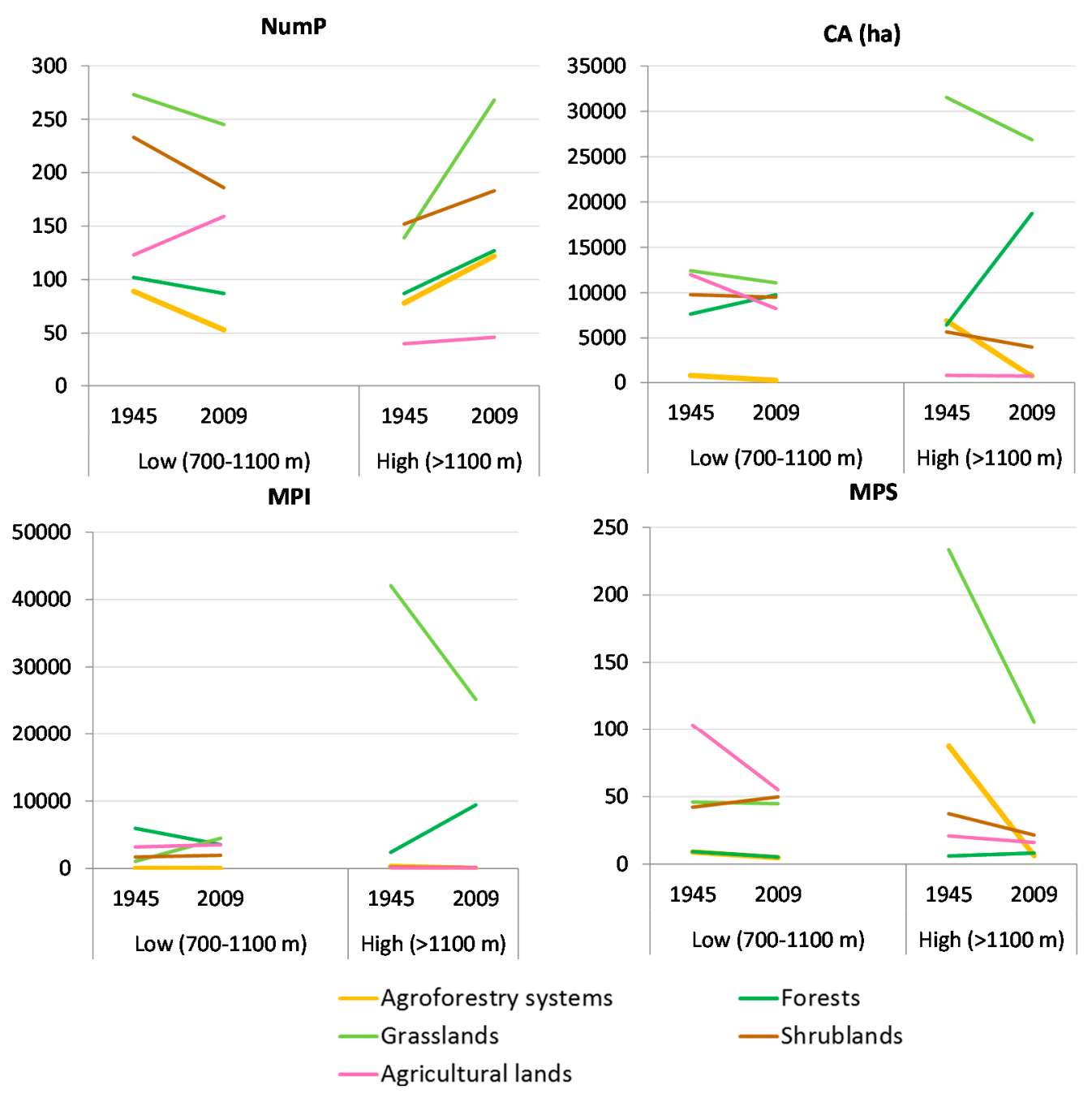

Figure 10. Class metrics per altitudinal zone on Mount Vermio between 1945 and 2009.

The number of patches (NumP) of forest cover and their average size (MPS), across the study area, represent significant land use changes within the study region. Since 1945, there has been a progressive decrease in transhumance practices in Mount Vermio [21], which led to the increase of forest cover in the uplands, indicated by the increase in the number (NumP) of forest patches, their average size (MPS), and the total cover (CA). This change has been observed in most North Mediterranean areas, in which agricultural and pastoral activities have declined, during the last 50 years $[73,96]$. In the low zone however, opposite trends were observed. Forest cover (CA) increased slightly but the number of patches (NumP) and mainly their average size (MPS) decreased, indicating a more continuous vegetation canopy. The undisrupted presence of animal husbandry in that area, resulting in an abiding landscape, may account for the observed differences between the two zones [68].

Agroforestry systems in the higher zone occupied large areas (CA) and were highly dispersed in the past (MPI) (Figure 10). Transhumance practices such as tree pollarding, shredding, and lopping [1,97,98], the use of timber for fire and constructions [32], woodcarving, loom making etc. [33], maintained an open, diversified landscape with scattered trees. The abandonment of these practices led to a 
significant decreased in both size (MPS) and spatial distribution (MPI) of agroforestry patches, leading to increased fragmentation and isolation. In the lowlands, the number of patches (NumP), average size (MPS), and proximity (MPI) of agroforestry systems decreased, but these changes were less intense, mostly because they occupied smaller area in this zone compared to the highlands $(>1100 \mathrm{~m})$.

The abandonment of transhumance practices triggered changes in both size and distribution of grassland patches. In the uplands, until 1945, landscape was dominated by large, well-distributed grasslands, as indicated by MPS and MPI respectively, controlled by grazing from sheep and goats, as well as from the large number of horses and mules. Nowadays however, patch number (NumP) increased, and average size (MPS) and proximity (MPI) decreased, thus grassland patches became more isolated and small (Figure 10). In the low zone, grasslands changes were less pronounced with the exception of a significant increase in their proximity (MPI). The continuous presence of grazing animals acted as regulator of grassland distribution stability.

Maintaining shrublands and agroforestry systems is useful not only for small ruminant feeding but also wildlife habitats [66]. Moreover, the preservation of transhumance livestock system in Greece, as well as other Mediterranean countries with semi-arid climate, is a critical element towards maintaining ecosystem function and sustainability [17].

\section{Conclusions}

In the Mediterranean area, pastoralism has played a key role in shaping mountainous landscapes [2]. Transhumance has been a pastoral practice fully adapted in Mediterranean ecosystems [99]. Socio-economic changes in the Mediterranean region during the last 50 years resulted mainly in the abandonment of pastoral activities in the mountainous area and a relative increase in forests $[96,100,101]$.

In Greece, rural abandonment, legislation, agricultural reform, and World War II, lead to the decline of transhumance practices. In Mount Vermio this triggered changes both in vegetation composition and spatial arrangement. There was a significant reduction of the area occupied by natural grasslands and a subsequent increase of forest size. This trend is more intense in the uplands due to the total abandonment of grazing opposite to only a partial reduction in the lowlands.

This study showed that the analysis of landscape structure can provide valuable insights on the driving forces shaping Mediterranean landscapes. Landscape configuration can be a useful tool for natural resource management and biodiversity conservation.

\section{Acknowledgments}

This paper is part of the project "The dynamics of the transhumant sheep and goat farming system in Greece. Influences on biodiversity" which is co-funded by the European Union (European Social Fund) through the Action "THALIS".

\section{Author Contributions}

Anna Sidiropoulou performed the research, reviewed the literature, analyzed the data, calculated landscape indicators, and contributed in designing the study and writing the manuscript. Maria Karatassiou, the principal investigator of the "Thalis" project, coordinated the research and contributed 
in designing the study and writing the paper. Georgia Galidaki developed the digital maps of the land use and Paraskevi Sklavou contributed in writing the paper. All authors read and approved the final manuscript.

\section{Conflicts of Interest}

The authors declare no conflict of interest.

\section{References}

1. Ispikoudis, I.; Sioliou, M.; Papanastasis, V. Transhumance in greece: Past, present and future prospects. In Transhumance and Biodiversity in European Mountains; Bunce, R., Pérez-Soba, M., Jongman, R., Gómez Sal, A., Herzog, F., Austad, I., Eds.; IALE Publication: Wageningen, The Netherland, 2004; pp. 211-229.

2. Oteros-Rozas, E.; Ontillera-Sánchez, R.; Sanosa, P.; Gómez-Baggethun, E.; Reyes-García, V.; González, J.A. Traditional Ecological Knowledge among Transhumant Pastoralists in Mediterranean Spain. 2013. Available online: http://dlc.dlib.indiana.edu/dlc/bitstream/handle/10535/ 9135/ES-2013-5597.pdf?sequence=1\&isAllowed=y (accessed on 19 November 2015).

3. Galanopoulos, K.; Abas, Z.; Laga, V.; Hatziminaoglou, I.; Boyazoglu, J. The technical efficiency of transhumance sheep and goat farms and the effect of eu subsidies: Do small farms benefit more than large farms? Small Rumin. Res. 2011, 100, 1-7.

4. Blondel, J. The 'design' of mediterranean landscapes: A millennial story of humans and ecological systems during the historic period. Hum. Ecol. 2006, 34, 713-729.

5. Oteros-Rozas, E.; González, J.A.; Martín-López, B.; López, C.A.; Montes, C. Ecosystem services and social-ecological resilience in transhumance cultural landscapes: Learning from the past, looking for a future. In Resilience and the Cultural Landscape. Understanding and Managing Change in Human-Shaped Environments; Plieninger, T., Bieling, C., Eds.; Cambridge University Press: Cambridge, UK, 2012; pp. 242-260.

6. Pardini, A.; Nori, M. Agro-silvo-pastoral systems in italy: Integration and diversification. Pastoralism 2011, doi:10.1186/2041-7136-1-26.

7. Zervas, G. Quantifying and optimizing grazing regimes in greek mountain systems. J. Appl. Ecol. 1998, 35, 983-986.

8. Goltsiou, K. Research Theme: Routes of Transhumance-Research Report for Greece. 2011. Available online: http://www.prismanet.gr/canepal/en-10-research-topics/en-4-transhumanceroutes/item/317-transhumance-routes-in-greece(accessed on 17 November 2015).

9. Martín, P.G. The history and characteristics of the mesteña transhumance routes. In Transhumance and Biodiversity in European Mountains; Bunce, R., Pérez-Soba, M., Jongman, R., Gómez Sal, A., Herzog, F., Austad, I., Eds.; IALE Publication: Wageningen, The Netherland, 2004; pp. 255-258.

10. Ntassiou, C. Department of Civil Engineering, Aristotle Univesity of Thessaloniki, Thessaloniki, Greece. American Military Geographic Service (AMS). Topographic maps 1953-1955. Personal communication, 2015. 
11. Caballero, R.; Fernández-González, F.; Badia, R.P.; Molle, G.; Roggero, P.P.; Bagella, S.; D’Ottavio, P.; Papanastasis, V.P.; Fotiadis, G.; Sidiropoulou, A.; et al. Grazing systems and biodiversity in mediterranean areas: Spain, italy and greece. Pastos 2011, doi:10.1111/j.13652494.2011.00820.x.

12. Casasús, I.; Bernués, A.; Sanz, A.; Riedel, J.; Revilla, R. Utilization of mediterranean forest pastures by suckler cows: Animal performance and impact on vegetation dynamics. In Animal Production and Natural Resources Utilisation in the Mediterranean Mountain Areas; Georgoudis, A., Rosati, A., Mosconi, C., Eds.; EAAP Scientific Series: Ioannina, Greece, 2005; Volume 115, pp. 82-88.

13. Kourakly, P.; Sidiropoulou, A.; Kostopoulou, P.; Ispikoudis, I. Impacts of livestock husbandry on the landscape. In Animal Production and Natural Resources Utilization in the Mediterranean Mountain Areas; Georgoudis, A., Rosati, A., Mosconi, C., Eds.; EAAP Scientific Series: Ioannina, Greece, 2005; Volume 115, pp. 220-223.

14. Bailey, D.; Dumont, B.; Wallis De Vries, M.F. Utilization of heterogeneous grasslands by domestic herbivores: Theory to management. Ann. Zootech. 1998, 47, 321-333.

15. Sternberg, M.; Gutman, M.; Perevolotsky, A.; Ungar, E.D.; Kigel, J. Vegetation response to grazing management in a mediterranean herbaceous community: A functional group approach. J. Appl. Ecol. 2000, 37, 224-237.

16. Vrahnakis, M.; Kyriazopoulos, A.; Fotiadis, G.; Sidiropoulou, A.; Dionisopoulou, A. Changes in components of floristic diversity in three adjacent rangeland types. Grassl. Sci. Eur. 2005, 10, $144-148$.

17. Karatassiou, M.; Parissi, Z.; Sklavou, P.; Ispikoudis, S. The impact of transhumant livestock system on the diversity of two mountainous grasslands in northern Greece. Options Méditerr. Ser. 2014, 109, 499-503.

18. Adler, P.B.; Raff, D.A.; Lauenroth, W.K. The effect of grazing on the spatial heterogeneity of vegetation. Oecologia 2001, 128, 465-479.

19. Perevolotsky, A. Integrating landscape ecology in the conservation of mediterranean ecosystems: The israeli experience. Isr. J. Plant Sci. 2005, 53, 203-213.

20. Coppolillo, P.B. Central-place analysis and modeling of landscape-scale resource use in an east african agropastoral system. Landsc. Ecol. 2001, 16, 205-219.

21. Sklavou, P.; Karatassiou, M.; Sidiropoulou, A. The role of transhumance in the evolution of vegetation and landscape: A case study in northern Greece (Vermio mountain). In Rangelands-Livestock: Research and Development; Kuriazopoulos, A., Karatassiou, M., Sklavou, P., Chouvardas, D., Eds.; Hellenic Rangeland Society, M.E.E.C.C.: Thessaloniki, Greece, 2014; pp. 59-64. (In Greek)

22. Ispikoudis, I.; Lyrintzis, G.; Kyriakakis, S. Impact of human activities on mediterranean landscapes in western crete. Landsc. Urban Plan. 1993, 24, 259-271.

23. Noy-Meir, I. Interactive effects of fire and grazing on structure and diversity of mediterranean grasslands. J. Veg. Sci. 1995, 6, 701-710. 
24. Riecken, U.; Finck, P.; Schröder, E. Significance of pasture landscapes for nature conservation and extensive agriculture. In Pasture Landscapes and Nature Conservation; Redecker, B., Härdtle, W., Finck, P., Riecken, U., Schröder, E., Eds.; Springer: Heidelberg, Germany, 2002; pp. 423-435.

25. Olsson, E.G.; Austrheim, G.; Grenne, S. Landscape change patterns in mountains, land use and environmental diversity, mid-norway 1960-1993. Landsc. Ecol. 2000, 15, 155-170.

26. Halstead, P. Pastoralism or household herding? Problems of scale and specialization in early greek animal husbandry. World Archaeol. 1996, 28, 20-42.

27. Papanastasis, V.P.; Arianoutsou, M.; Papanastasis, K. Environmental conservation in classical greece. J. Biol. Res. 2010, 14, 123-135.

28. Hadjigeorgiou, I. Past, present and future of pastoralism in greece. Pastoralism 2011, doi:10.1186/2041-7136-1-24.

29. Höeg, C. Les Saracatsans, Une Tribu Nomade GrecqueEdouard Champion: Paris, France, 1925. (In French)

30. Cusumano, C. Greece, a Love Story; Seal Press: Berkeley, CA, USA, 2007.

31. Kavvadias, G. Pasteurs-Nomades Mediterranéens: Les Saracatsans de Grèce; Gauthier-Villars: Paris, France, 1965. (In French)

32. Katsaros, N. Ta Sarakatsanika Tseligkata tou Vermiou; Syllogos Sarakatsanaion Perfecture Imathias "Oi Stavraetoi”: Alexandria Imathias, Greece, 2009. (In Greek)

33. Chatzimichali, A. Sarakatsanoi, 2nd ed.; Angeliki Chatzimichali Foundation: Athina, Greece, 2007. (In Greek)

34. Sirkou, D.; Skarlatou, A. Sarakatsani of epirus. In Range Science on the Threshold of 21th Century; Papachristou, T., Dini-Papanastasi, O., Eds.; Hellenic Rangeland Society: Ioannina, Greece, 2001; pp. 65-69. (In Greek)

35. Dong, S.; Wen, L.; Liu, S.; Zhang, X.; Lassoie, J.; Yi, S. Vulnerability of worldwide pastoralism to global changes and interdisciplinary strategies for sustainable pastoralism. 2011. Available online: http://www.ecologyandsociety.org/vol16/iss2/art10/ (accessed on 17 November 2015).

36. Kavvadias, G. Sarakatsanoi: A Greek Pastoral Society; Lousi Mpratzioti Publishing: Athens, Greece, 1991. (In Greek)

37. Leitão, A.B.; Ahern, J. Applying landscape ecological concepts and metrics in sustainable landscape planning. Landsc. Urban Plan. 2002, 59, 65-93.

38. Tucker, G.M.; Graham, M.; Evans, M.I. Habitats for Birds in Europe: A Conservation Strategy for the Wider Environment; BirdLife International: Cambridge, UK, 1997.

39. Gillanders, S.N.; Coops, N.C.; Wulder, M.A.; Gergel, S.E.; Nelson, T. Multitemporal remote sensing of landscape dynamics and pattern change: Describing natural and anthropogenic trends. Prog. Phys. Geogr. 2008, 32, 503-528.

40. Bankov, N. Dynamics of land cover/use changes in relation to socio-economic condition in the psilorites mountain of crete, greece. Master's Thesis, Mediterranean Agronomic Institute of Chania, Chania, Greece, 1998.

41. Farina, A. Principles and Methods in Landscape Ecology; Springer: The Netherlands, UK, 1998.

42. Turner, M.G. Landscape ecology: The effect of pattern on process. Annu. Rev. Ecol. Syst. 1989, 20, 171-197. 
43. Wu, J.; Hobbs, R. Key issues and research priorities in landscape ecology: An idiosyncratic synthesis. Landsc. Ecol. 2002, 17, 355-365.

44. O’Neill, R.V.; Milne, B.T.; Turner, M.G.; Gardner, R.H. Resource utilization scales and landscape pattern. Landsc. Ecol. 1988, 2, 63-69.

45. Turner, M.G.; Gardner, R.H. Quantitative Methods in Landscape Ecology; Springer-Verlag: New York, NY, USA, 1991.

46. McGarigal, K.; Marks, B.J. Fragstat: Spatial Pattern Analysis Program for Quantifying Landscape Structure. 1995. Available online: http://andrewsforest.oregonstate.edu/pubs/pdf/ pub1538.pdf (accessed on 17 November 2015).

47. Wang, A.H.; Zhang, S.Q.; Zhang, B. A study on the change of spatial pattern of wetland in the Sanjiang plain. Acta Ecol. Sin. 2003, 23, 237-243.

48. Sidiropoulou, A. Analysis and evaluation of agroforestry systems using landscape indicators. Ph.D. Thesis, Aristotle University of Thessaloniki, Thessaloniki, Greece, October 2011. (In Greek)

49. Corry, R.C.; Lafortezza, R. Sensitivity of landscape measurements to changing grain size for fine-scale design and management. Landsc. Ecol. Eng. 2007, 3, 47-53.

50. Plexida, S.G.; Sfougaris, A.I.; Ispikoudis, I.P.; Papanastasis, V.P. Selecting landscape metrics as indicators of spatial heterogeneity-a comparison among greek landscapes. Int. J. Appl. Earth Obs. Geoinf. 2014, 26, 26-35.

51. Sidiropoulou, A.; Mantzanas, K.; Vrahnakis, M.; Ispikoudis, I. Inventory and landscape structure analysis of agrosilvopastoral systems in florina regional unit. In Dry Grasslands of Europe: Grazing and Ecosystem Services; Vrahnakis, M., Kyriazopoulos, A.P., Chouvardas D., Fotiadis, G., Eds.; HERPAS: Thessaloniki, Greece, 2013; pp. 318-324.

52. Crews-Meyer, K. Characterizing landscape dynamism using paneled-pattern metrics. Photogramm. Eng. Remote Sens. 2002, 68, 1031-1040.

53. Ricca, N.; Guagliardi, I. Multi-temporal dynamics of land use patterns in a site of community importance in southern Italy. Appl. Ecol. Environ. Res. 2015, 13, 677-691.

54. European Commission (EC). Statistical Information Needed for the Indicators to Monitor the Integration of Environmental Concerns into the Common Agricultural Policy. 2001. Available online: http://eur-lex.europa.eu/legal-content/EN/TXT/?uri=celex:52006DC0508 (accessed on 17 November 2015).

55. Lausch, A.; Herzog, F. Applicability of landscape metrics for the monitoring of landscape change: Issues of scale, resolution and interpretability. Ecol. Indic. 2002, 2, 3-15.

56. O’Neill, R.V.; Hunsaker, C.T.; Jones, K.B.; Riitters, K.H.; Wickham, J.D.; Schwartz, P.M.; Goodman, I.A.; Jackson, B.L.; Baillargeon, W.S. Monitoring environmental quality at the landscape scale. Bioscience 1997, 47, 513-519.

57. Wascher, D.M.; Pérez-Soba, M. Learning from European Transfrontier Landscapes. 2004. Available online: http://www.landscape-europe.net/images/files/whole3web\%20II.pdf (accessed on 17 November 2015).

58. Zorn, P.; Stephenson, W.; Grigoriev, P. An ecosystem management program and assessment process for Ontario national parks. Conserv. Biol. 2001, 15, 353-362.

59. Haines-Young, R.; Chopping, M. Quantifying landscape structure: A review of landscape indices and their application to forested landscapes. Prog. Phys. Geogr. 1996, 20, 418-445. 
60. Forman, R.T.T.; Godron, M. Landscape Ecology; John Wiley \& sons: Hoboken, NJ, USA 1986.

61. Collinge, S.K. Ecological consequences of habitat fragmentation: Implications for landscape architecture and planning. Landsc. Urban Plan. 1996, 36, 59-77.

62. Gustafson, E.J. Quantifying landscape spatial pattern: What is the state of the art? Ecosystems 1998, $1,143-156$.

63. Meini, M.; Adducchio, D.; Ciliberti, D.; Di Felice, G. Landscape conservation and valorization by satellite imagery and historic maps. The case of italian transhumance routes. Eur. J. Remote Sens. 2014, 47, 375-387.

64. Sarno, E. Historical Maps and Gis Environment as Integrated Methodology to Rediscovery of Cattle-Track Landscapes. A Case Study. 2014. Available online: https://www.academia.edu/ 8735813/HISTORICAL_MAPS_AND_GIS_ENVIRONMENT_AS_INTEGRATED_METHOD OLOGY_TO_REDISCOVERY_OF_CATTLE-TRACK_LANDSCAPES._A_CASE_STUDY (accessed on 17 November 2015).

65. Russo, P.; Riguccio, L.; Carullo, L.; Tomaselli, G. Parametric analysis of the changes a landscape previously used for transhumance in a nature reserve in sicily. Nat. Resour. 2014, 5, 213-224.

66. Olea, P.P.; Mateo-Tomás, P. The role of traditional farming practices in ecosystem conservation: The case of transhumance and vultures. Biol. Conserv. 2009, 142, 1844-1853.

67. Mitka, A.; Chouvardas, D.; Ispikoudis, I. Temporal landscape changes (1963-1998) at the region of "kopatsari" in the prefecture of grevena. In Range Science and Life Quality; Sidiropoulou, A., Mantzanas, K., Ispikoudis, I., Eds.; Hellenic Rangeland Society: Xanthi, Greece, 2010; pp. 97-102. (In Greek)

68. Chochliouros, S. Floristic and phytosociological research of mount vermion: An ecological approach. Ph.D. Thesis, University of Patras, Patra, Greece, June 2005. (In Greek)

69. Zianis, D.; Mencuccini, M. Aboveground biomass relationships for beech (fagus moesiaca cz.) trees in vermio mountain, northern greece, and generalised equations for fagus sp. Ann. For. Sci. 2003, 60, 439-448.

70. National Cadastre and Mapping Agency S.A. Aerial Photographs; NCMA S.A: Athens, Greece, 1945.

71. NASA LP DAAC, U.S. Geological Survey. ASTER Global Digital Elevation Model V001, Version: V001. Sioux Falls, South Dakota, USA. 2009. Available online: https://lpdaac.usgs.gov/ (accessed on 20 November 2015).

72. ESRI. Arcmap TM: Release 10.1; Environmental Systems Resource Institute: Redlands, CA, USA, 2011.

73. Geri, F.; Amici, V.; Rocchini, D. Human activity impact on the heterogeneity of a mediterranean landscape. Appl. Geogr. 2010, 30, 370-379.

74. Herzog, F.; Lausch, A.; Muller, E.; Thulke, H.-H.; Steinhardt, U.T.A.; Lehmann, S. Landscape metrics for assessment of landscape destruction and rehabilitation. Environ. Manag. 2001, 27, 91-107.

75. John, R.; Chen, J.; Lu, N.; Wilske, B. Land cover/land use change in semi-arid Inner Mongolia: 1992-2004. Environ. Res. Lett. 2009, 4, Article 4. 
76. Elkie, P.C.; Rempel, R.S.; Carr, A. Patch Analyst User's Manual: A Tool for Quantifying Landscape Structure; Ontario Ministry of Natural Resources, Boreal Science, Northwest Science \& Technology: Thunder Bay, ON, Canada, 1999.

77. Dunn, C.P.; Sharpe, D.M.; Guntenspergen, G.R.; Steams, F.; Yang, Z. Methods for analyzing temporal changes in landscape pattern. In Quantitative Methods in Landscape Ecology, the Analysis and Interpretation of Landscape Heterogeneity; Turner, M.G., Gardner, R.H., Eds.; Springer-Verlag: New York, NY, USA, 1991; Volume 82, pp. 173-198.

78. Moreira, F.; Rego, F.; Ferreira, P. Temporal (1958-1995) pattern of change in a cultural landscape of northwestern Portugal: Implications for fire occurrence. Landsc. Ecol. 2001, 16, $557-567$.

79. Turner, M.; Ruscher, C.L. Changes in landscape patterns in Georgia, USA. Landsc. Ecol. 1988, $1,241-251$.

80. Atauri, J.A.; De Lucio, J.V. The role of landscape structure in species richness distribution of birds, amphibians, reptiles and lepidopterans in mediterranean landscapes. Landsc. Ecol. 2001, 16, 147-159.

81. McGarigal, K.; McComb, W.C. Relationships between landscape structure and breeding birds in the oregon coast range. Ecol. Monogr. 1995, 65, 235-260.

82. Botequilha Leitão, A.; Miller, J.; Ahern, K.; McGarigal, K. Measuring Landscapes: A Planner's Handbook; Island Press: Washington, DC, USA, 2006.

83. Franklin, J.; Forman, R.T. Creating landscape patterns by forest cutting: Ecological consequences and principles. Landsc. Ecol. 1987, 1, 5-18.

84. Bender, D.J.; Contreras, T.A.; Fahrig, L. Habitat loss and population decline: A meta-analysis of patch size effect. Ecology 1998, 79, 517-533.

85. Gustafson, E.; Parker, G. Relationships between landcover proportion and indices of landscape spatial pattern. Landsc. Ecol. 1992, 7, 101-110.

86. Haken, H. Information and Self-Organization: A Macroscopic Approach to Complex Systems (Springer Series in Synergetics); Springer-Verlag NY: New York, USA, 2006.

87. Prigogine, I. The End of Certainty: Time, Chaos, and the New Laws of Nature; Free Press: New York, NY, USA, 1997.

88. Cowling, R.M.; Rundel, P.W.; Lamont, B.B.; Arroyo, M.K.; Arianoutsou, M. Plant diversity in mediterranean-climate regions. Trends Ecol. Evol. 1996, 11, 362-366.

89. Naveh, Z.; Whittaker, R.H. Structural and floristic diversity of shrublands and woodlands in northern Israel and other mediterranean areas. Vegetatio 1980, 41, 171-190.

90. Noy-Meir, I. Effects of grazing on mediterranean grasslands: The community level. In Ecological Basis of Livestock Grazing in Mediterranean Ecosystems, Proceeding of the International Occasional Symposium of EGF 4, Thessaloniki, Greece, 23-25 October 1997; Papanastasis, V.P., Peter, D., Eds.; pp. 27-39.

91. Payment and Control Agency for Guidance and Guarantee Community Aid (PCAGGCA). Registry of Farms and Farmers; Ministry of Rural Development and Food: Athens, Greece, 2011.

92. Oteros-Rozas, E.; Martín-López, B.; López, C.A.; Palomo, I.; González, J.A. Envisioning the future of transhumant pastoralism through participatory scenario planning: A case study in Spain. Rangel. J. 2013, 35, 251-272. 
93. Ainalis, A.; Meliadis, I.; Tsiouvaras, K.; Ainali, K.; Platis, D.; Platis, P. Multitemporal land use ochanges in a region of Pindus mountain, central Greece. Agric. For. Fish. 2015, 4, 18-23.

94. Davies, J.; Hatfield, R. The economics of mobile pastoralism: A global summary. Nomadic Peoples 2007, 11, 91-116.

95. Lasanta-Martínez, T.; Vicente-Serrano, S.M.; Cuadrat-Prats, J.M. Mountain mediterranean landscape evolution caused by the abandonment of traditional primary activities: A study of the Spanish central pyrenees. Appl. Geogr. 2005, 25, 47-65.

96. Agnoletti, M. The degradation of traditional landscape in a mountain area of tuscany during the 19th and 20th centuries: Implications for biodiversity and sustainable management. For. Ecol. Manag. 2007, 249, 5-17.

97. Sidiropoulou, A.; Ispikoudis, I. Ancient trees as indicators of agroforestry systems-three case studies from northern Greece. In Woodland Cultures in Time and Space-Tales from the Past, Messages for the Future; Saratsi, E., Bórgi, M., Johann, E., Kirby, K., Moreno, D., Watkins, C., Eds.; Embryo Publications: Athens, Greece, 2009; pp. 138-144.

98. Vrahnakis, M.S.; Fotiadis, G.; Pantera, A.; Papadopoulos, A.; Papanastasis, V.P. Floristic diversity of valonia oak silvopastoral woodlands in Greece. Agrofor. Syst. 2014, 88, 877-893.

99. Bunce, R.; Pérez-Soba, M.; Jongman, R.; Gómez Sal, A.; Herzog, F.; Austad, I. Transhumance and Biodiversity in European Mountains. 2004. Available online: http://www.jbjordal.no/ publikasjoner/Transhumance.pdf (accessed on 17 November 2015).

100. Antrop, M. Landscape change and the urbanization process in Europe. Landsc. Urban Plan. 2004, 67, 9-26.

101. Romero-Calcerrada, R.; Perry, G.L.W. The role of land abandonment in landscape dynamics in the spa 'encinares del río alberche y cofio, central Spain, 1984-1999. Landsc. Urban Plan. 2004, $66,217-232$.

(C) 2015 by the authors; licensee MDPI, Basel, Switzerland. This article is an open access article distributed under the terms and conditions of the Creative Commons Attribution license (http://creativecommons.org/licenses/by/4.0/). 